\title{
Rapid wastage of the Hazen Plateau ice caps, northeastern Ellesmere Island, Nunavut, Canada
}

\author{
Mark C. Serreze ${ }^{1}$, Bruce Raup ${ }^{2}$, Carsten Braun ${ }^{3}$, Douglas R. Hardy ${ }^{4}$, and Raymond S. Bradley ${ }^{4}$ \\ ${ }^{1}$ Department of Geography, and Cooperative Institute for Research in Environmental Sciences, \\ University of Colorado, Boulder, Colorado, USA \\ ${ }^{2}$ Cooperative Institute for Research in Environmental Sciences, University of Colorado, Boulder, Colorado, USA \\ ${ }^{3}$ Geography and Regional Planning/Environmental Science, Westfield State University, Westfield, Massachusetts, USA \\ ${ }^{4}$ Department of Geosciences, University of Massachusetts, Amherst, Massachusetts, USA
}

Correspondence to: Mark C. Serreze (serreze@nsidc.org)

Received: 24 August 2016 - Published in The Cryosphere Discuss.: 9 September 2016

Revised: 7 November 2016 - Accepted: 24 December 2016 - Published: 25 January 2017

\begin{abstract}
Two pairs of small stagnant ice bodies on the Hazen Plateau of northeastern Ellesmere Island, the St. Patrick Bay ice caps and the Murray and Simmons ice caps, are rapidly shrinking, and the remnants of the St. Patrick Bay ice caps are likely to disappear entirely within the next 5 years. Vertical aerial photographs of these Little Ice Age relics taken during August of 1959 show that the larger of the St. Patrick Bay ice caps had an area of $7.48 \mathrm{~km}^{2}$ and the smaller one $2.93 \mathrm{~km}^{2}$; the Murray and Simmons ice caps covered 4.37 and $7.45 \mathrm{~km}^{2}$ respectively. Outlines determined from ASTER satellite data for July 2016 show that, compared to 1959, the larger and the smaller of the St. Patrick Bay ice caps had both been reduced to only $5 \%$ of their former area, with the Murray and Simmons ice caps faring better at 39 and $25 \%$, likely reflecting their higher elevation. Consistent with findings from other glaciological studies in the Queen Elizabeth Islands, ASTER imagery in conjunction with past GPS surveys documents a strikingly rapid wastage of the St. Patrick Bay ice caps over the last 15 years. These two ice caps shrank noticeably even between 2014 and 2015, apparently in direct response to the especially warm summer of 2015 over northeastern Ellesmere Island. The welldocumented recession patterns of the Hazen Plateau ice caps over the last $55+$ years offer an opportunity to examine the processes of plant recolonization of polar landscapes.
\end{abstract}

\section{Introduction}

The Hazen Plateau of northeastern Ellesmere Island, Nunavut, Canada, is a rolling upland, with elevations rising from about $300 \mathrm{~m}$ above sea level (a.s.1.) near Lake Hazen to over $1000 \mathrm{~m}$ along the northeastern coast of the island. The plateau is unglaciated with the exception of two pairs of small stagnant ice caps - the unofficially named St. Patrick Bay ice caps and, $110 \mathrm{~km}$ to the southwest, the Murray and Simmons ice caps (Fig. 1). They are collectively referred to here as the Hazen Plateau ice caps. As of 2001, the larger St. Patrick Bay ice cap ranged in elevation between about 880 and $720 \mathrm{~m}$ a.s.l., with the smaller one spanning 820 to $700 \mathrm{~m}$. The Murray and Simmons ice caps lie in higher terrain; in 2001, both fell between about 1100 and $1000 \mathrm{ma.s.1}$. The Hazen Plateau ice caps are interpreted as forming and attaining their maximum extents during the Little Ice Age (LIA, ca. 1600-1850) (Koerner, 1989). Like much of the Queen Elizabeth Islands, the Hazen Plateau is presently a polar desert; annual precipitation is typically only $150-200 \mathrm{~mm}$, with a late summer and early autumn maximum (Serreze and Barry, 2014). Summer precipitation may be variously rain or snow. Summers are very cool but variable; assessed as part of a multiyear glaciological study (Braun et al., 2004), the average $10 \mathrm{~m}$ July air temperatures at the Murray Ice Cap summit $(1100 \mathrm{~m})$ measured for the years 1999 through 2001, respectively, were $4.0,0.2$, and $1.6^{\circ} \mathrm{C}$.

This paper documents the behavior of the Hazen Plateau ice caps over the past 55+ years in the context of other glaciological studies in the Canadian Arctic. The analysis is 
Table 1. Directly measured mass balances (meter water equivalent) of the Hazen Plateau ice caps. Where a value represents a multiyear record, the average annual value is shown in parentheses. Asterisks denote minimum estimates.

\begin{tabular}{lrrrr}
\hline $\begin{array}{l}\text { Balance year } \\
\text { or period }\end{array}$ & $\begin{array}{r}\text { Large St. } \\
\text { Patrick Bay }\end{array}$ & $\begin{array}{r}\text { Small St. } \\
\text { Patrick Bay }\end{array}$ & Murray & Simmons \\
\hline $1971 / 72$ & $+0.14^{1}$ & - & - & - \\
$1971 / 72-1981 / 82$ & $-1.3^{2}(-0.14)^{2}$ & - & - & - \\
$1975 / 76-1982 / 83$ & - & - & - & $*-0.49(-0.08)^{2}$ \\
$1981 / 82$ & $*-0.14^{2}$ & - & - & - \\
$1982 / 83$ & $+0.14^{2}$ & - & - & - \\
$1983 / 84-1997 / 98$ & - & - & - & $*-0.49(-0.03)^{4}$ \\
$1983 / 84-1999 / 00$ & $*-1.01(-0.06)^{3}$ & $*-1.26^{3}(-0.07)^{3}$ & - & - \\
$1998 / 99$ & - & - & $-0.49^{3}$ & - \\
$1999 / 00$ & - & - & $-0.29^{3}$ & $-0.40^{3}$ \\
$2000 / 01$ & - & - & $-0.47^{3}$ & $-0.52^{3}$ \\
$2001 / 02$ & - & - & $-0.29^{3}$ & - \\
\hline
\end{tabular}

Sources: ${ }^{1}$ Hattersley-Smith and Serson (1973); ${ }^{2}$ Bradley and Serreze (1987); ${ }^{3}$ Braun et al. (2004).

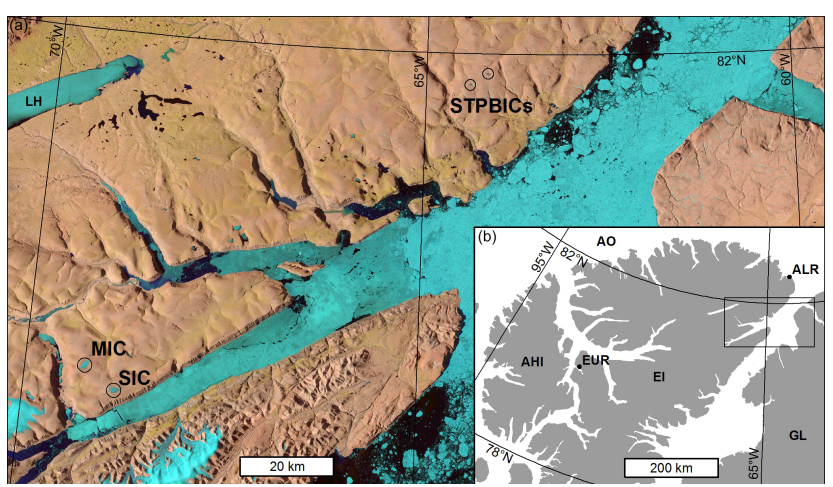

Figure 1. The location of the St. Patrick Bay (STPBIC), Murray (MIC), and Simmons (SIC) ice caps. The inset map shows Ellesmere Island (EL), Axel Heiberg Island (AHI), Greenland (GL), the Arctic Ocean (AO), and stations Alert (ALR) and Eureka (EUR). Use is made of $850 \mathrm{hPa}$ temperature data from the Alert radiosonde record and precipitation records from Eureka.

based on a combination of past work using aerial photography, direct mass balance measurements from several field investigations, and GPS surveys of ice cap areas collected as part of these investigations - along with new information on ice cap areas using data at $15 \mathrm{~m}$ resolution from the ASTER (Advanced Spaceborne Thermal Emission and Reflection Radiometer) instrument. ASTER flies onboard the NASA's Earth Observing System Terra satellite, launched in December 1999. It provides reflectance at a $15 \mathrm{~m}$ resolution and is a key asset of the international GLIMS initiative (Global Land Ice Measurements from Space) for mapping glacier outlines (Raup et al., 2007; Kargel et al., 2014).

\section{Previous work}

Table 1 lists all available direct mass balance estimates of the ice caps (in meters water equivalent, or $m$ w.e.). Table 2 provides all available estimates of ice cap areas $\left(\mathrm{km}^{2}\right)$. The first information on the St. Patrick Bay ice caps that we are aware of is oblique aerial photographs taken in late July of 1947 as part of the US Operation Polaris Trimetregon Survey. These photographs show the ice caps standing out prominently against the snow-free tundra surface. Vertical aerial photographs collected by the Canada Department of Energy, Mines and Resources followed in August of 1959. These photographs show prominent, exposed surface dirt layers and stratigraphic layering on the St. Patrick Bay ice caps, and the Murray and Simmons ice caps are also bare of snow. From digitizing the 1959 photographs and mapping the ice cap outlines, the larger of the St. Patrick Bay ice caps then had an area of $7.48 \mathrm{~km}^{2}$ and the smaller one $2.94 \mathrm{~km}^{2}$. The Murray and Simmons ice caps covered, respectively, 4.37 and $7.45 \mathrm{~km}^{2}$ (Serreze, 1985; Bradley and Serreze, 1987; Braun et al., 2004). We estimate that these areas are accurate to within $5 \%$.

In July of 1972, Canadian scientists H. Serson and J. A. Morrison surveyed the larger of the two St. Patrick Bay ice caps. They landed by helicopter in foul weather to find the ice cap totally covered with snow. They installed eight accumulation stakes along a roughly $2 \mathrm{~km}$ transect partway across the ice cap. The range in elevation along this transect was about $60 \mathrm{~m}$, which compares to a range for the entire ice cap of about $160 \mathrm{~m}$. Later that same summer, on 20-21 August, the ice cap was visited by G. Hattersley-Smith and A. Davidson, who noted a "partial cover of winter snow all around the ice margins for at least a kilometer" (HattersleySmith and Serson, 1973), in striking contrast to conditions depicted in the August 1947 and 1959 aerial photographs. 
Table 2. Surface areas $\left(\mathrm{km}^{2}\right)$ and $\%$ areas compared to 1959 aerial photographs.

\begin{tabular}{|c|c|c|c|c|c|c|c|c|}
\hline \multirow[b]{2}{*}{1959} & \multicolumn{2}{|c|}{$\begin{array}{c}\text { Larger St. Patrick Bay ice } \\
\text { cap area and \% of } 1959\end{array}$} & \multicolumn{2}{|c|}{$\begin{array}{l}\text { Smaller St. Patrick Bay ice } \\
\text { cap area and \% of } 1959\end{array}$} & \multicolumn{2}{|c|}{$\begin{array}{c}\text { Murray Ice Cap area } \\
\text { and \% of } 1959\end{array}$} & \multicolumn{2}{|c|}{$\begin{array}{c}\text { Simmons Ice Cap area } \\
\text { and } \% \text { of } 1959\end{array}$} \\
\hline & $7.48^{1}$ & $100 \%$ & $2.94^{1}$ & $100 \%$ & $4.37^{1}$ & $100 \%$ & $7.45^{1}$ & $100 \%$ \\
\hline 1978 & $6.69^{1}$ & $89 \%$ & $2.74^{1}$ & $93 \%$ & - & - & - & - \\
\hline 1999 & - & - & - & - & $3.28^{2}$ & $75 \%$ & - & - \\
\hline 2000 & - & - & - & - & $3.15^{2}$ & $72 \%$ & - & - \\
\hline 2001 & $4.61^{2}$ & $62 \%$ & $1.72^{2}$ & $58 \%$ & $3.05^{2}\left(3.08^{4}\right)$ & $70 \%$ & $3.94^{2}\left(3.83^{4}\right)$ & $53 \%$ \\
\hline 2003 & - & - & - & - & $2.91^{3}$ & $66 \%$ & $3.31^{3}$ & $44 \%$ \\
\hline 2005 & $3.68^{4}$ & $49 \%$ & $1.03^{4}$ & $35 \%$ & - & - & - & - \\
\hline 2006 & - & - & - & - & $2.86^{3}$ & $65 \%$ & $3.19^{3}$ & $43 \%$ \\
\hline 2007 & - & - & - & - & $2.76^{4}$ & $63 \%$ & $2.92^{4}$ & $39 \%$ \\
\hline 2009 & $2.54^{4}$ & $34 \%$ & $0.63^{4}$ & $21 \%$ & - & - & - & - \\
\hline 2014 & $1.03^{4}$ & $14 \%$ & $0.29^{4}$ & $10 \%$ & - & - & - & - \\
\hline 2015 & $0.52^{4}$ & $7 \%$ & $0.18^{4}$ & $6 \%$ & - & - & - & - \\
\hline 2016 & $0.35^{4}$ & $5 \%$ & $0.15^{4}$ & $5 \%$ & $1.72^{4}$ & $39 \%$ & $1.84^{4}$ & $25 \%$ \\
\hline
\end{tabular}

${ }^{1}$ Aerial photographs. ${ }^{2}$ Surface GPS surveys (Braun et al., 2004). ${ }^{3}$ GPS helicopter surveys. ${ }^{4}$ ASTER.

They concluded that while the ice cap had been in decline (as suggested from the 1947 and 1959 photographs), by the early 1970s it had returned to good health, "thickening slightly and extending its margins" (icy firn was observed atop the dirty melt surface and a perennial snow cover extended beyond the ice cap margins). This is consistent with a known shift towards cooler summers and increased precipitation over the eastern Canadian Arctic (Bradley and Miller, 1972; Bradley and England, 1978). Hattersley-Smith and Serson estimated a mass balance for the $1971 / 1972$ season of $+0.14 \mathrm{~m}$ w.e.

In 1982 and 1983, the St. Patrick Bay ice caps were the focus of detailed energy and mass balance investigations (Serreze, 1985; Bradley and Serreze, 1987; Serreze and Bradley, 1987). The stake network was expanded on the larger St. Patrick Bay ice cap and several stakes were installed on the smaller one. At the end of the 1982 field season in early August, the entire ice cap was bare ice with a well-developed cryoconite surface. Assuming that the 1982 melt season had largely ended by early August (all visible melt had stopped by the time that the field camp had been evacuated), the 1981/1982 mass balance for the larger ice cap was estimated at $-0.14 \mathrm{~m}$ w.e. Given that more melt may have occurred, this is likely a minimum estimate. Based on the stake line installed in 1972, Bradley and Serreze (1987) estimated that the overall mass balance for the period 1972-1982 was approximately $-1.3 \mathrm{~m}$ w.e. $\left(-0.14 \mathrm{a}^{-1}\right)$. This result finds qualitative support in comparisons between the 1959 aerial photographs and subsequent vertical aerial photographs taken on 1 August 1978 showing that the larger and smaller of the ice caps had decreased in area by 7 and $11 \%$ over that interval. Like the 1959 photographs, the August 1978 photographs revealed a snow-free plateau and bare ice with a prominent ablation surface. Aerial photographs taken 4 years earlier, on 4 August 1974, showed broadly similar conditions. As part of the St. Patrick Bay Project, a network of stakes installed on the Simmons Ice Cap in 1976 (Bradley and England, 1977) was re-surveyed on 11 July 1983. Of the 18 original stakes, only 6 could be located; the others were presumed to have melted out. Based on these sparse data, Bradley and Serreze (1987) estimated that over the period 1976-1983, the Simmons Ice Cap experienced a total mass loss of at least $-0.49 \mathrm{~m}$ w.e. $\left(-0.08 \mathrm{a}^{-1}\right)$. Collectively, these observations provided strong evidence that the period of recovery inferred by Hattersley-Smith and Serson (1973) was short-lived.

However, the summer of 1983 was cool, and the snow never completely melted off the surrounding tundra. The 1982/1983 annual mass balance for the larger St. Patrick Bay ice cap was estimated at $+0.14 \mathrm{~m}$ w.e., and given their higher elevation it is reasonable to assume that the 1982/1983 balance year for the Simmons and Murray ice caps was also positive.

To our knowledge, there were no further visits to the Hazen Plateau ice caps until 1999, when C. Braun, D. Hardy, and R. Bradley of the University of Massachusetts Amherst established a network of 11 accumulation stakes on the Murray Ice Cap, which they further expanded in the year 2000. A new network of 15 stakes was established on the Simmons Ice Cap in 2000. Winter snow accumulation was measured on both ice caps in late May of 1999 through 2001, and summer ablation was measured in late July and early August from 1999-2002. For the 4 years analyzed, 1999-2002, annual balances of both ice caps were negative in all years, ranging from $-0.29 \mathrm{~m}$ w.e. (Murray Ice Cap in 2000 ) to $-0.52 \mathrm{~m}$ w.e. (Simmons Ice Cap in 2001). In the summer of 2001, C. Braun and D. Hardy used portable GPS to survey the perimeter of all four ice caps. The larger and smaller of the St. Patrick Bay ice caps had shrunk to 62 and $59 \%$ of their 1959 areas respectively. The Murray and Simmons ice caps had shrunk 


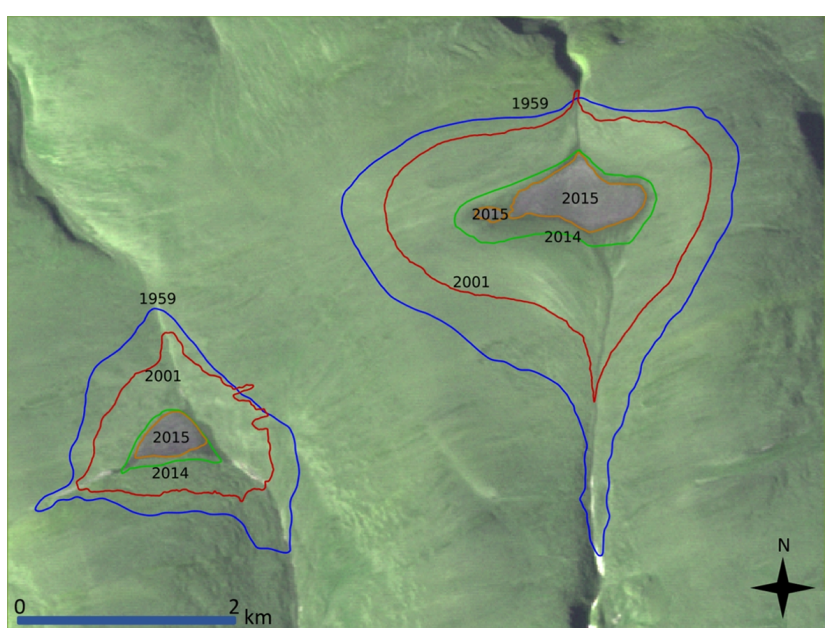

Figure 2. Outlines of the St. Patrick Bay ice caps based on aerial photography from August 1959, GPS surveys conducted during August 2001, and for August of 2014 and 2015 from ASTER. The base image is from August 2015.

to 70 and $53 \%$ of their 1959 areas. Some of the accumulation stakes inserted into the larger St. Patrick Bay ice cap in 1982 and 1983 were located but all had melted out. Knowing how deep they had been originally inserted enabled a minimum estimate $\left(-1.01 \mathrm{~m}\right.$ w.e., $\left.-0.06 \mathrm{a}^{-1}\right)$ of the mass loss between 1984 and 2000. This is based on the mean remaining depth of stake insertion into the ice in 1983 and an assumed ice density of $900 \mathrm{~kg} \mathrm{~m}^{3}$ (Braun et al., 2004). In the late summer of 2003, C. Braun mapped the margins of the Murray and Simmons ice caps via portable GPS by holding the device out the window of a low-flying helicopter. The same approach was used to assess the ice cap margins in 2006, this time by University of Massachusetts graduate student T. Cook.

\section{Updated history, 1959-2016}

\subsection{Ice cap areas}

The use of ASTER in conjunction with the air photographs and GPS surveys enables a fairly detailed assessment of changes in ice cap areas from 1959 through the present. Clear-sky late summer (July-August) scenes of the St. Patrick Bay ice caps showing a strong brightness contrast between the ice and the bare, dark plateau surface, enabled manual mapping of the ice cap perimeters from ASTER for the years 2005, 2009, 2014, 2015, and 2016. For the Murray and Simmons ice caps, ASTER estimates were obtained for 2001, 2007, and 2016. For 2001, areas of the Murray and Simmons were available from both ASTER and the surfacebased GPS surveys. Considering the GPS surveys for this year as ground truth, the ASTER areas for this year are accurate to within $1 \%$ for the Murray Ice Cap and $3 \%$ for the Simmons Ice Cap. It is assumed that this is representative

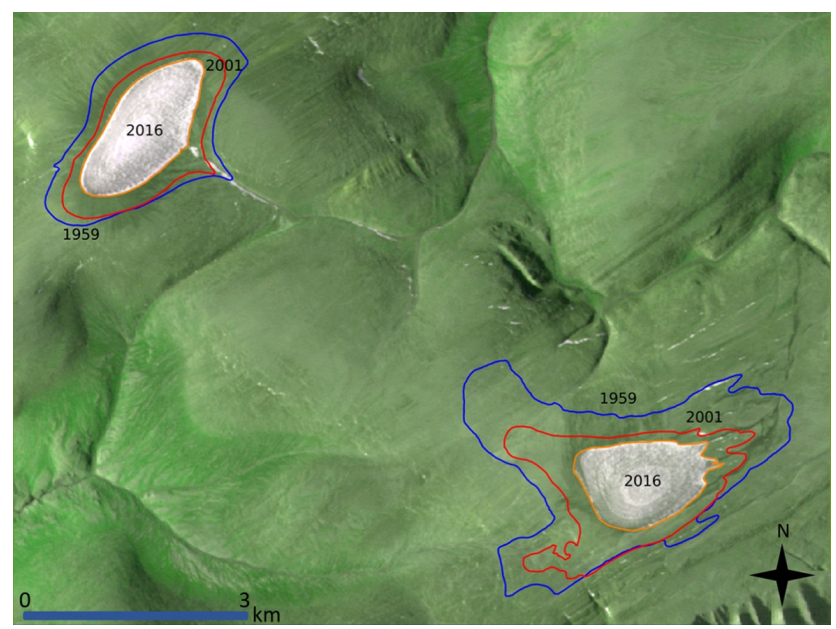

Figure 3. Outlines of the Murray and Simmons ice caps based on aerial photography from August 1959, GPS surveys conducted during August 2001, and for July 2016 from ASTER. The base image is from August 2016.

of the accuracy of area mapping from ASTER for the other years.

As of July 2016, and Murray and Simmons ice caps cover 39 and $25 \%$ of the areas in 1959 based on the aerial photographs. By sharp contrast, both of the St. Patrick Bay ice caps in 2016 cover only $5 \%$ of their former areas and have been reduced to ice patches, with the smaller ice body now covering only $0.15 \mathrm{~km}^{2}$.

Outlines of the St. Patrick Bay ice caps for 1959 from aerial photography, for 2001 from GPS surveys, and for 2014 and 2015 from ASTER are shown in Fig. 2. The reductions in ice cap area are striking. Note the obvious shrinkage even between the years 2014 and 2015. Shrinkage of the Murray and Simmons ice caps is shown in Fig. 3, based on outlines from 1959, 2001, and 2016. The shrinkage of these two ice caps is clearly evident, albeit less pronounced.

Using the area estimates through 2002 and extrapolating forward, Braun et al. (2004) suggested that the Hazen Plateau ice caps would disappear by the middle of the 21 st century or soon thereafter and that, given their larger size, the Simmons Ice Cap and the larger of the two St. Patrick Bay ice caps would be the last to go. However, based on data through 2016 and extrapolating forward (Fig. 4), it now appears that both of the St. Patrick Bay ice caps will disappear around the year 2020.

From the analyses described above, and results from other glaciological investigations for the Canadian Arctic and the Arctic as a whole, the following conclusions are drawn:

- The Hazen Plateau ice caps are unlikely to be relics of the last glacial maximum but rather likely formed during the LIA (ca. 1600-1850) (Koerner, 1989). They may have retained their LIA extents through the first couple of decades of the 20th century (Hattersley-Smith, 


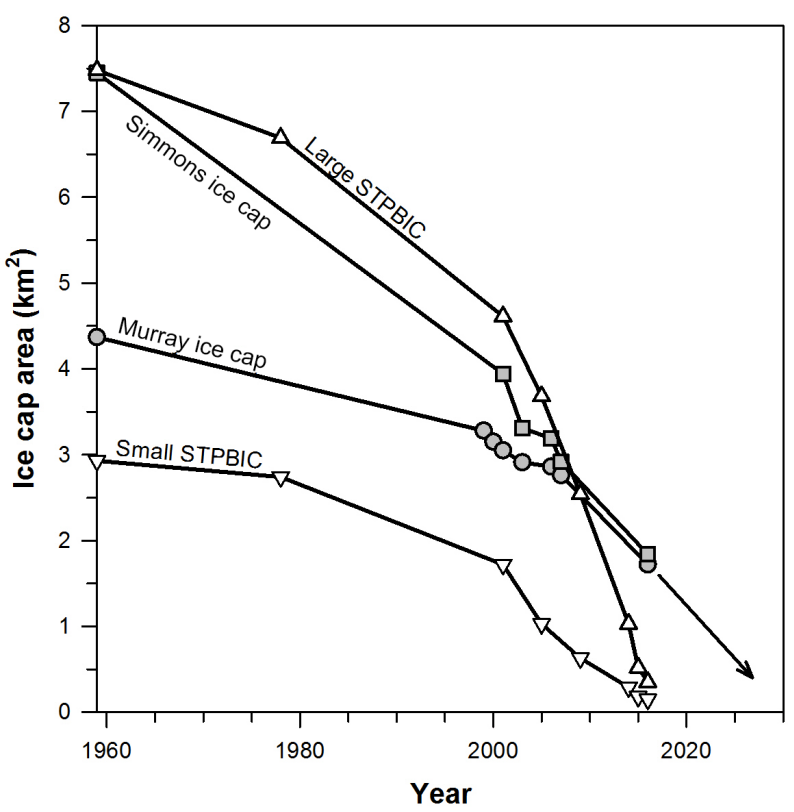

Figure 4. Time history of ice cap areas and projected times of disappearance.

1969; Sharp et al., 2014) but have been in overall decline ever since. Braun et al. (2004) speculate on the basis of a mapped lichen trim line that the Murray Ice Cap may have attained a maximum LIA extent of about $9.6 \mathrm{~km}^{2}$, over twice the mapped 1959 area of $4.35 \mathrm{~km}^{2}$. Similar trim lines were observed around the other three ice caps and, although not mapped in detail, strongly point to much more extensive ice cover during the LIA. To place these findings in a broader context, for the Queen Elizabeth Islands as a whole, trim lines based on high-resolution satellite imagery point to a $37 \%$ reduction in perennial snow and ice extent between the LIA maximum extent and the year 1960. Over the lowerlying central and western islands, a complete removal of perennial snow and ice occurred by 1960 (Wolken et al., 2008).

- From the 1960s through part of the 1970s, the ice caps may have experienced a period of reduced loss or occasional growth $(1971 / 1972,1982 / 1983)$ in response to cooling. This basic pattern likely holds for monitored Canadian Arctic glaciers and ice caps as a whole (Bradley and Miller, 1972; Hattersley-Smith and Serson, 1973; Ommanney, 1977; Bradley and England, 1978; Braun et al., 2004; Sharp et al., 2014).

- Since then, apart from occasional years such as $1982 / 1983$, annual mass balances of the four ice caps have been persistently negative (Braun et al., 2004). This is in turn consistent with the broader pattern of reductions in mass and area of Arctic glaciers and ice caps (Dowdeswell et al., 1997; Dyurgerov and Meier,
1997; Arendt et al., 2002; Koerner, 2005; Sharp et al., 2011, 2014; Fisher et al., 2012; Mortimer et al., 2016). It is also consistent with a negative mass balance of the Greenland Ice Sheet since at least the 1990s (Shepherd et al., 2012).

Mass balance summaries for four monitored glaciers and ice caps in the Canadian Arctic (Devon Ice Cap, Meighen Ice Cap, Melville South Ice Cap, and the White Glacier) are provided as part of the American Meteorological Society (AMS) State of the Climate reports. As assessed over the period 1980 through 2010, all four have had negative average annual mass balances, ranging from $-0.15 \mathrm{~m}$ w.e. for the Devon Ice Cap to $-0.29 \mathrm{~m}$ w.e. for the Melville South Ice Cap (AMS, 2016). Cumulative changes in regional total stored water for the period 2003 through 2015 based on gravimetric data from the GRACE mission (Gravity Recovery and Climate Experiment) are qualitatively consistent with these mass balance measurements (AMS, 2016). Based on ice core data, Fisher et al. (2012) document rapid acceleration of ice cap melt rates of over the last few decades across the entire Canadian Arctic; the large reductions in area of the Hazen Plateau ice caps, in particular the lower-elevation St. Patrick Bay ice caps, are consistent with this finding. However, reflecting variable climate conditions, annual balances are also quite variable. For example, for the 2013/2014 balance year (the most recent data available), the White Glacier had a strongly negative balance $(-0.42 \mathrm{~m}$ w.e.) while the small Meighen Ice Cap actually gained mass (+0.06) (AMS, 2016). Sharp et al. (2014) show that while the larger ice bodies in the Canadian Arctic have seen the largest losses in mass, the smaller masses have lost a larger proportion on their areas. This is also consistent with the behavior of the Hazen Plateau ice caps. Below we examine variability in climate conditions over the Hazen Plateau and links to mass balance and area changes.

\subsection{Associated climate conditions}

The annual mass balance of low-accumulation ice caps and glaciers in the Canadian High Arctic is known to be primarily governed by summer warmth rather than winter accumulation (e.g., Bradley and England, 1978; Koerner, 2005). To place the behavior of the Hazen Plateau ice caps in a climate context, use is made of summer-averaged (June through August) $850 \mathrm{hPa}$ temperature anomalies from the radiosonde record at Alert, located on the northeastern coast of Ellesmere Island (Fig. 1) along with estimated summer temperature anomalies for the LIA. The Alert radiosonde record extends back to 1957. We use monthly mean records contained in the Integrated Global Radiosonde Archive (IGRA; Durre et al., 2006), based on daily 00:00 and 12:00 UTC soundings. Summer averages (JJA) were eliminated if based on fewer than 70 values. The $850 \mathrm{hPa}$ level is about $1400 \mathrm{~m}$ a.s.l. for a standard atmosphere, hence roughly 600-700 m above the surface in the vicinity of the St. Patrick Bay ice caps and 300-400 $\mathrm{m}$ above the surface in the vicin- 


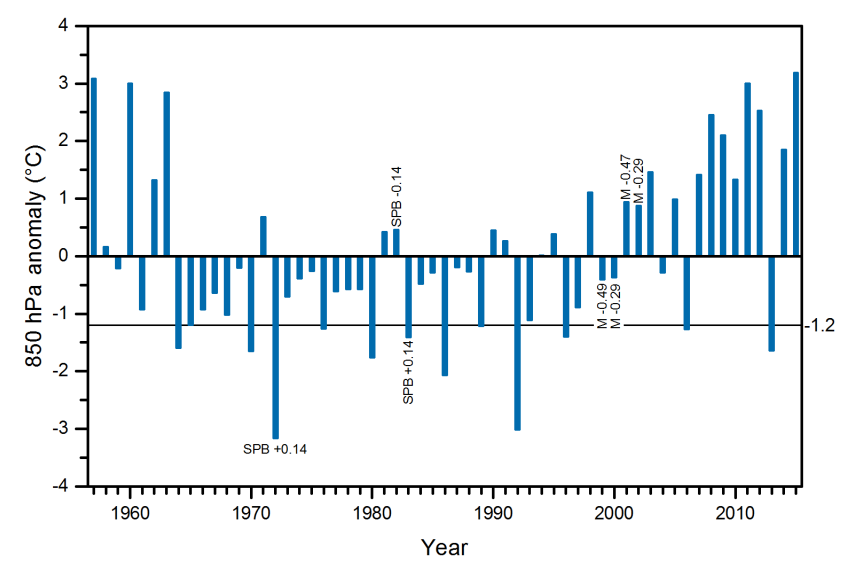

Figure 5. Temperature anomalies at the $850 \mathrm{hPa}$ level $\left({ }^{\circ} \mathrm{C}\right)$ over the period 1957-2016 (referenced to the period 1981-2010) from the Alert radiosonde record. The horizontal black line shows the estimated summer average Arctic temperature anomaly for the LIA relative to $1981-2010\left(-1.2^{\circ} \mathrm{C}\right)$. Also shown are the annual mass balance estimates for the larger St. Patrick Bay (SBP) ice caps for the 1981/1982 and 1982/1983 balance years and for the Murray Ice Cap (M) for the 1999/2000, 2000/2001, 2001/2002, and 2002/2003 balance years (in $\mathrm{m}$ w.e.).

ity of the Murray and Simmons ice caps. While arguably it might be better to look at the $925 \mathrm{hPa}$ level as it is closer to the plateau surface, this level has many missing values in the IGRA record. The time series of anomalies, computed with respect to the standard averaging period 1981-2010, follows in Fig. 5.

Kaufman et al. (2009) took advantage of a variety of proxy sources (e.g., tree rings, ice cores, lake cores) to assemble a record of Arctic summer surface temperature anomalies that extend back 2000 years. From their analysis, LIA summer Arctic temperatures anomalies averaged around $-0.6^{\circ} \mathrm{C}$ with respect to a 1961-1990 reference period. The $1961-$ 1990 summer mean of $-3.2^{\circ} \mathrm{C}$ from the radiosonde data compares to a mean of $-2.6^{\circ} \mathrm{C}$ for $1981-2000$. The latter period is hence about $0.6^{\circ} \mathrm{C}$ warmer. With the assumption that (a) temperature anomalies at $850 \mathrm{hPa}$ have been similar to those at the surface (supported by Sharp et al., 2011, in their analysis of Canadian Arctic ice caps but possibly complicated by the temperature inversion structure) and (b) LIA conditions over the Hazen Plateau were at least broadly similar to those for the Arctic as a whole, these results imply that Arctic LIA temperature anomalies were about $-1.2^{\circ} \mathrm{C}$ relative to a 1981-2000 baseline. This estimated LIA temperature anomaly is also shown in Fig. 5.

If it is also accepted that the ice caps were broadly in equilibrium with average LIA summer temperatures, Fig. 5 suggests generally strong negative annual balances from the beginning of the record through the early 1960s. This was followed by smaller negative and occasionally positive annual balances from the middle of the 1960s through about 2000 and a preponderance of strong negative balances from the beginning of the century through the present. For comparison with the radiosonde record, we also examined $850 \mathrm{hPa}$ summer temperatures over the Hazen Plateau from the National Centers for Environmental Prediction/National Center for Atmospheric Research (NCEP/NCAR) reanalysis (Kalnay et al., 1996) which extend back to 1948. Given that the Alert radiosonde data are assimilated into the reanalysis, it follows that the radiosonde and NCEP/NCAR time series look similar for the period of overlap. The NCEP/NCAR records suggest that the period 1948-1956 not covered by the IGRA record was warm overall with mostly positive anomalies relative to the 1981-2000 baseline. The cooling between the late 1940s through the middle 1960s broadly corresponds to the cooling over the eastern Canadian Arctic such as discussed by Bradley and Miller (1972), Bradley and England (1978), and other studies. The time series of decadal mean summer temperatures at the $700 \mathrm{hPa}$ level for the major glaciated regions of the Canadian Arctic presented by Sharp et al. (2011) based on the NCEP/NCAR reanalysis (their Fig. 9.3) is also consistent with the pattern shown in Fig. 5.

An examination of selected individual years is instructive. Based on summer 1957 temperatures, the 1956/1957 annual balance must have been strongly negative. The same can be said for $1959 / 1960$ and 1962/1963. By sharp contrast, the summer of 1972, when Hattersley-Smith and Serson (1973) visited the ice caps and remarked upon the extensive $\mathrm{Au}$ gust snow cover over the plateau and estimated a positive balance of $+0.14 \mathrm{~m}$ w.e. (for the $1971 / 1972$ season), was the coldest in the radiosonde record and about $2^{\circ} \mathrm{C}$ below the estimated LIA average. There is also a clear contrast between 1982 (a known negative annual balance year for the St. Patrick Bay ice caps) and 1983 (a known positive balance year, with summer $850 \mathrm{hPa}$ temperatures slightly below the LIA average). Given the low temperatures for the summer of 1992, which followed the 1991 eruption of Mt. Pinatubo, the balance for 1991/1992 was likely positive. In the sense that summer temperatures were above the estimated LIA average, negative balances for the Murray ice caps for 1998/1999 through 2001/2002 (Braun et al., 2004) are all consistent with Fig. 5. Note, however, that the largest negative balance of -0.49 m w.e. for $1999 / 2000$ corresponds to the coldest of the four summers, arguing for influences of local effects on summer temperature or perhaps a low winter accumulation.

Regarding the summer of 2013, the obvious exception to the pattern of recent warm years, the ASTER data and daily images from the Moderate Resolution Imaging Spectroradiometer (MODIS) show extensive cloud cover through the summer, making it difficult to determine whether the snow cover ever entirely cleared off the plateau. It is likely, however, that the 2012/2013 balance year was positive for the Hazen Plateau ice caps - the Devon Ice Cap, Meighen Ice Cap, and the White Glacier all gained mass. Only the Melville South Ice Cap, lying well to the west, had a negative balance (AMS, 2014). Consistent with this view, 


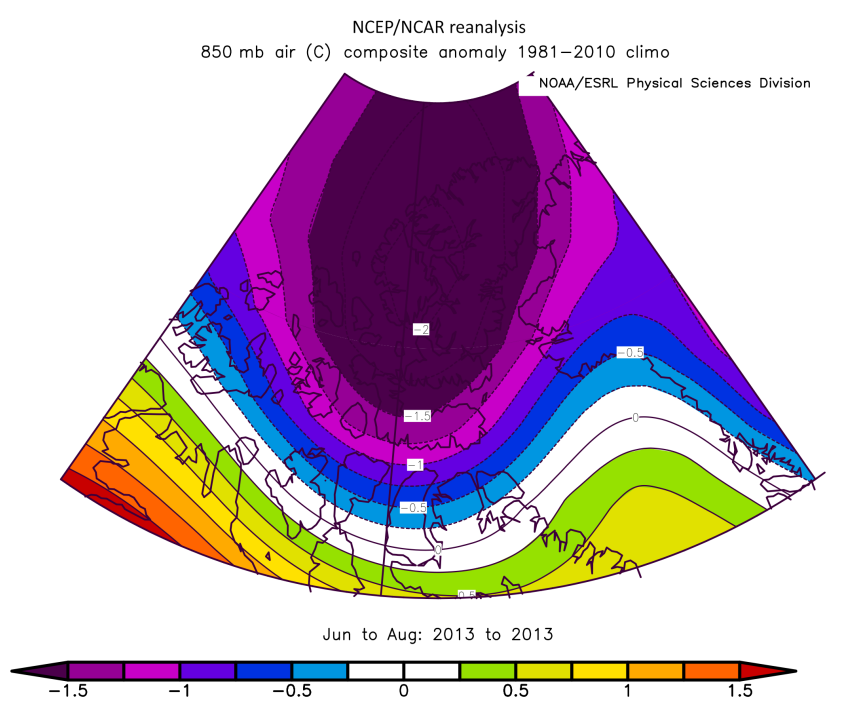

Figure 6. Summer (JJA) 2013 air temperature anomalies at the $850 \mathrm{hPa}$ level from the NCEP/NCAR reanalysis relative to a 19812010 baseline.

Fig. 6 shows that summer (JJA) averaged $850 \mathrm{hPa}$ temperature anomalies over the Queen Elizabeth Islands from the NCEP/NCAR reanalysis were about $2{ }^{\circ} \mathrm{C}$ below the $1981-$ 2010 baseline in the area centered over Axel Heiberg and Ellesmere islands. This reflects the influence of an unusually deep circumpolar vortex at the $500 \mathrm{hPa}$ level, centered just south of the North Pole along about $90^{\circ} \mathrm{W}$ longitude. By sharp contrast, the notable area reduction of the St. Patrick Bay ice caps between August 2014 and 2015 aligns with the very warm summer of 2015, essentially tied with 1957 as the highest in the record. From Fig. 7, July 2015 temperatures at the $850 \mathrm{hPa}$ level from the NCEP/NCAR reanalysis were $3-4{ }^{\circ} \mathrm{C}$ above the $1981-2010$ baseline over most of northeastern Ellesmere Island. Mass balance estimates for monitored glaciers in the Queen Elizabeth Islands for the 2014/2015 season that would provide context were not available us at the time that this paper came to press.

\section{Conclusions}

Regarding accelerating wastage of the St. Patrick Bay ice caps since the dawn of the 21 st century, the outsized warming of the Arctic in recent decades compared to the rest of the Northern Hemisphere (termed Arctic amplification) is overall most strongly expressed during the cold season, and is not nearly as prominent in summer (Serreze and Barry, 2011). Nevertheless, from the NASA Goddard Institute for Space Sciences (GISS) analysis (http://data.giss.nasa.gov/ gistemp/), the trend in July surface air temperatures over northeastern Ellesmere Island over the period 1960-2015 is about $2{ }^{\circ} \mathrm{C}$ (expressed as a total change) which stands out compared to the rest of the Arctic. On the basis of a satellite-

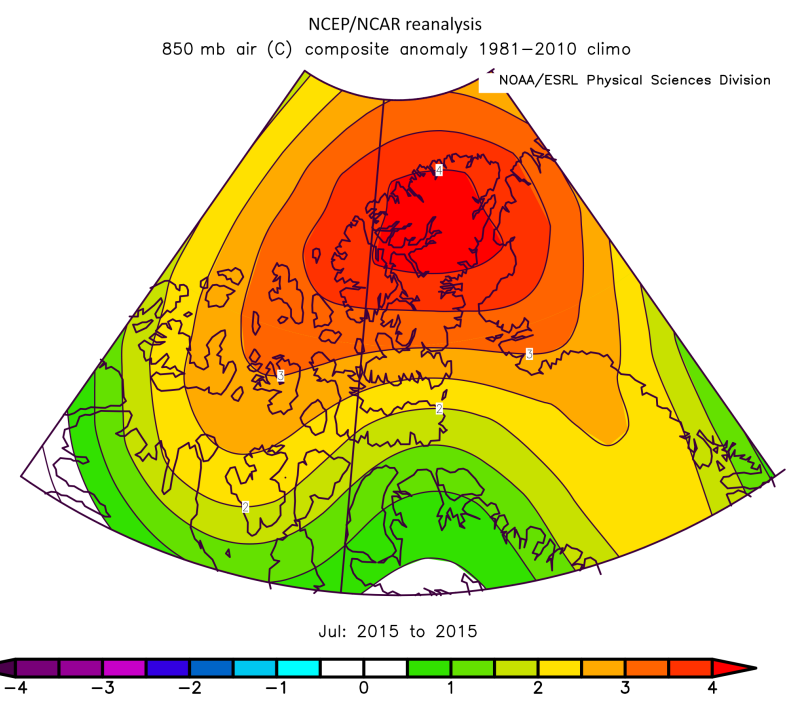

Figure 7. July 2015 air temperature anomalies at the $850 \mathrm{hPa}$ level from the NCEP/NCAR reanalysis relative to a 1981-2010 baseline.

derived record (from MODIS) of summer land surface temperatures, the more recent period of 2000 to 2015 has seen an average warming rate over the Queen Elizabeth Islands of $0.06^{\circ} \mathrm{C}$ year $^{-1}$, or a total of nearly $1.0^{\circ} \mathrm{C}$, most of this occurring between 2005 and 2012 (Mortimer et al., 2016). They associate this warming with increasingly negative mass balances for glaciers and ice caps in the region. However, conditions over the Hazen Plateau are highly variable; the summers of 1957, 1960, and 1963 were almost as warm as those seen in 2015, and the summer of 2013 was quite cool, very likely resulting in a positive balance for 2012/2013.

Rapid wastage of the St. Patrick Bay ice caps over the past 15 years likely also reflects a reduction in summer albedo, as dirt layers become progressively exposed and accumulate at the surface. During the 1982 and 1983 field campaigns, it was observed that summer precipitation over the ice caps was typically in the form of snow, temporarily increasing the surface albedo and adding some mass. The frequency of summer snowfall has likely declined in the (generally) sharply warming climate over the past 15 years. Also, as suggested from the prominent decline in the area of the larger St. Patrick Bay ice cap between 2014 and 2015, when there is an especially warm summer, the thin collar of ice at the ice cap margins (a feature evident in field observations) will be prone to completely melting. The less pronounced area reduction of the Murray and Simmons ice caps must partly be due to their higher elevation and relatively cooler summer conditions. However, the elevation difference is only about 200-300 m, which argues that the stronger response of the St. Patrick Bay ice caps to warming may also be related to ice thickness. Regional differences in the temperature lapse rate (notably the temperature inversion structure) could also be involved. 
It is possible that the Hazen Plateau caps could see some temporary recovery given the large natural variability in the Arctic. However, as noted by Alt (1978) and Bradley and England (1978), for stagnant ice caps such as these, all it takes is one warm summer to erase any accumulated mass gains of a previous decade. Assessing variability and trends in Arctic precipitation is notoriously difficult but, as evaluated over the period 1950-2007, annual precipitation has generally increased across Canada and especially across Northern Canada. For example, at station Eureka in central Ellesmere Island (see Fig. 1), annual precipitation appears to have increased by at least $40 \%$ (Zhang et al., 2011). Trends over the plateau are not known, but this suggests that, if anything, precipitation changes are helping to buffer the ice caps from summer mass loss.

Paradoxically, perhaps, loss of the Hazen Plateau ice caps may open new research opportunities. As they recede, plant remains are exposed that can be dated and used to better understand the past climate history of the region. From radiocarbon dates on rooted tundra plants exposed by receding cold-based ice caps on Baffin Island - given that the plants are killed when the snow line drops below the collection sites - Miller et al. (2013) were able to construct a record of summer temperatures over Arctic Canada for the past 5000 years. La Farge et al. (2013) discovered that ice loss in Sverdrup Pass, Ellesmere Island, has exposed nearly intact plant communities for which radiocarbon dates point to entombment during the LIA. They also found that these recently exposed, subglacial bryophytes can regenerate, which may have important implications for recolonization of polar landscapes. The area surrounding the receding Hazen Plateau ice caps provides a unique opportunity to examine this process of recolonization in the High Arctic, as the rates of ice recession are now well-documented for the last $55+$ years (Table 1).

\section{Data availability}

Radiosonde data for station Alert are available at the Integrated Global Radiosonde Archive (ftp://ftp.ncdc.noaa.gov/ pub/data/igra/). ASTER data can be obtained through the NASA Land Processes DAAC (https://lpdaac.usgs.gov/).

Author contributions. M. Serreze led the overall effort. C. Braun, D. Hardy, and R. S. Bradley provided GPS data and historical documents. B. Raup analyzed the ASTER data. All authors contributed to the writing.

Competing interests. The authors declare that they have no conflict of interest.
Acknowledgements. This study was supported by the University of Colorado Boulder, the NASA Snow and Ice DAAC award NNG13HQ033 to the University of Colorado, and NSF Award 9819362 to the University of Massachusetts.

Edited by: C. Haas

Reviewed by: D. Burgess and M. Sharp

\section{References}

Alt, B.: Synoptic climate controls of mass balance variations on Devon Island Ice Cap, Arc. Alp. Res., 10, 61-80, 1978.

American Meteorological Society: State of the Climate in 2014, edited by: Blunden, J. S. and Arndt, D. S., Special Supplement to the Bulletin of the American Meteorological Society, 96, 267 pp., 2014.

American Meteorological Society: State of the Climate in 2015, edited by: Blunden, J. S. and Arndt, D. S., Special Supplement to the Bulletin of the American Meteorological Society, 97, 275 pp., 2015.

Arendt, A. A., Echelmeyer, K. A., Harrison, W. D., Lingle, C. S., and Valentine, V. B.: Rapid wastage of Alaska glaciers and their contribution to rising sea level, Science, 297, 382-385, 2002.

Bradley, R. S. and England, J. (Eds.): The Simmonds Ice Cap, in: Past Glacial Activity in the High Arctic, University of Massachusetts Amherst, Department of Geology and Geography, 177-182, 1977.

Bradley, R. S. and England, J.: Recent climatic fluctuations of the Canadian High Arctic and their significance for glaciology, Arc. Alp. Res., 10, 715-731, 1978.

Bradley, R. S. and Miller, G. H.: Recent climatic change and increased glacierization in the eastern Canadian Arctic, Nature, 237, 385-387, 1972.

Bradley, R. S. and Serreze, M. C.: Mass balance of two high Arctic plateau ice caps, J. Glaciol., 33, 123-128, 1987.

Braun, C., Hardy, D. R., and Bradley, R. S.: Mass balance and area changes of four high Arctic plateau ice caps, Geogr. Ann. A, 86, 43-52, 2004.

Dowdeswell, J. A., Hagen, J. O., Bjornsson, H., Glazovsky, A. F., Harrison, W. D., Holmlund, P., Jania, J., Koerner, R. M., Lefauconnier, B., Ommanney, C. S. L., and Thomas, R. H.: The mass balance of circum-Arctic glaciers and recent climate change, Quat. Res., 48, 1-14, 1997.

Durre, I., Vose, R. S., and Wuetz, D. B.: Overview of the integrated global radiosonde archive, J. Climate, 19, 53-68, 2006.

Dyurgerov, M. B. and Meier, M. F.: Year-to-year fluctuation of global mass balance of small glaciers and their contribution to sea level changes, Arc. Alp. Res., 29, 392-402, 1997.

Fisher, D., Zheng, J. Burgess, D., Zdanowicz, C., Kinnard, C., Sharp, M., and Bourgeois, J.: Recent melt rates of Canadian arctic ice caps are the highest in four millennia, Global Planet. Change, 84-85, 3-7, doi:10.1016/j.gloplacha.2011.06.005,2012.

Gardner, A. S., Moholdt, G., Wouters, B., Wolken, G. J., Burgess, D. O., Sharp, M. J., Cogley, J. G., Braun, C., and Labine, C.: Sharp acceleration of mass loss from Canadian Arctic Archipelago glaciers and ice caps, Nature, 473, 357-360, 2011. 
Hattersley-Smith, G.: Glacial features of Tanquary Fiord and adjoining areas of Ellesmere Island, NWT, J. Glaciol., 8, 23-50, 1969.

Hattersley-Smith, G. and Serson, H.: Reconnaissance of a small ice cap near St. Patrick Bay, Robeson Channel, Northern Ellesmere Island, Canada, J. Glaciol., 12, 417-421, 1973.

Kalnay, E., Kanamitsu, M., Kistler, R., Collins, W., Deaven, D., Gandin, L., Iredell, M., Saha, S., White, G., Woollen, J., Zhu, Y., Leetmaa, A., Reynolds, R., Chelliah, M., Ebisuzaki, W., Higgins, W., Janowiak, J., Mo, K. C., Ropelewski, C., Wang, J., Jenne, R., and Joseph, D.: The NCEP/NCAR 40-year re-analysis project, B. Am. Meteorol. Soc., 77, 437-471, 1996.

Kargel, J. S., Leonard, G. J., Bishop, M. P., Kaab, A., and Raup, B. (Eds.): Global Land Ice Measurements from Space, SpringerPraxis, ISBN: 978-3-540-79817-0, 876 pp., 2014.

Kaufman, D. S., Schneider, D. P., McKay, N. P., Ammann, C. M., Bradley, R. S., Briffa, K. R., Miller, G. H., Otto-Bliesner, B. L., Overpeck, J. T., Vinther, B. M., and Arctic Lakes 2k Project Members: Recent warming reverses long-term Arctic cooling, Science, 325, 1236-1239, doi:10.1126/science.1173983, 2009.

Koerner, R. M.: Queen Elizabeth Island Glaciers, edited by: Fulton, R. J., Quaternary Geology of Canada and Greenland, Geology of Canada (No. 1), Geological Survey of Canada, 464-477, 1989.

Koerner, R. M.: Mass balance of glaciers in the Queen Elizabeth Islands, Nunavut, Canada, Ann. Glaciol., 42, 417-423, doi:10.3189/172756405781813122, 2005.

La Farge, C., Williams, K. H., and England, J. H.: Regeneration of Little Ice Age bryophytes emerging from a polar glacier with implications of totipotency in extreme environments, P. Natl. Acad. Sci. USA, 110, 9839-9844, doi:10.1073/pnas.1304199110, 2013.

Miller, G. H., Lehman, S. J., Refsnider, K. A., Southon, J. R., and Zhong, Y.: Unprecedented recent summer warmth in Arctic Canada, Geophys. Res. Lett., 40, 5745-5751, doi:10.1002/2013GL057188, 2013.

Mortimer, C. A., Sharp, M., and Wouters, B.: Glacier surface temperatures in the Canadian high Arctic, 2000-2015, J. Glaciol., 62, 963-975, doi:10.1017/jog.2016.80, 2016.

Ommanney, C. S. L.: Quadrennial Report to the Permanent Service on the Fluctuations of Glaciers on Canadian Glacier Variations and Mass Balance Changes, Fisheries and Environment Canada, Inland Waters Directorate, Glaciology Divisions, Ottawa, 1977.

Raup, B. H., Racoviteanu, A., Khalsa, S. J. S., Helm, C., Armstrong, R., and Arnaud, Y.: The GLIMS geospatial glacier database: a new tool for studying glacier change, Global Planet. Change, 56, 101-110, doi:10.1016/j.gloplacha.2006.07.018, 2007.
Serreze, M. C.: Topoclimatic Investigations of a Small, Sub-Polar Ice Cap with Implications for Glacierization, Masters Thesis, Department of Geology and Geography, University of Massachusetts, Amherst, 201 pp., 1985.

Serreze, M. C. and Barry, R. G.: Processes and impacts of Arctic amplification: A research synthesis, Global Plan. Change, 77, 85-96, 2011.

Serreze, M. C. and Barry, R. G.: The Arctic Climate System, 2nd Edn., Cambridge University Press, 404 pp., 2014.

Serreze, M. C. and Bradley, R. S.: Radiation and cloud observations on a high Arctic plateau ice cap, J. Glaciol., 33, 162-168, 1987.

Sharp, M., Burgess, D. O., Cogley, J. G., Ecclestone, M., Labine, C., and Wolken, G. J.: Extreme melt on Canada's Arctic ice caps in the 21st century, Geophys. Res. Lett., 38, L11501, doi:10.1029/2011GL047381, 2011.

Sharp, M., Burgess, D. O., Cawkwell, F., Copland, L., Davis, J. A., Dowdeswell, E. K., Dowdeswell, J. A., Gardner, A. S., Mair, D., Wang, L., Williamson, S. N., Wolken, G. J., and Wyatt, F.: Remote sensing of recent glacier changes in the Canadian Arctic, Chapter 9, in: Global Land Ice Measurements from Space, edited by: Kargel, J. S., Leonard, G. J., Bishop, M. P., Kääb, A., and Raup, B. H., Springer Praxis Books, 205-228, doi:10.1007/9783-540-79818-7_9, 2014.

Shepherd, A., Ivins, E. R., Geruo, A., Barletta, V. R., Bentley, M. J., Bettadpur, S., Briggs, K. H., Bromwich, D. H., Forsberg, R., Galin, N., Horwath, M., Jacobs, S., Joughin, I., King, M. A., Lenaerts, J. T. M., Li, J., Ligtenberg, S. R. M., Luckman, A., Luthcke, S. B., McMillan, M., Meister, R., Milne, G., Mouginot, J., Muir, A., Nicolas, J. P., Paden, J., Payne, A. J., Pritchard, H., Rignot, E., Rott, H., Sørensen, L. S., Scambos, T. A., Scheuchl, B., Schrama, E. J. O., Smith, B., Sundal, A. V., van Angelen, J. H., van de Berg, W. J., van den Broeke, M. R., Vaughan, D. G., Velicogna, I., Wahr, J., Whitehouse, P. L., Wingham, D. J., Yi, D., Young, D., and Zwally, H. J.: : A reconciled estimate of ice-sheet mass balance, Science, 338, 1183-1189, doi:10.1126/science.1228102, 2012.

Wolken, G. J., Sharp, M. L., and England, J. H.: Changes in late-Neoglacial perennial snow/ice extent and equilibrium-line altitudes in the Queen Elizabeth Islands, Arctic Canada, The Holocene, 18, 615-627, 2008.

Zhang, X., Brown, R., Vincent, L., Skinner, W., Feng, Y., and Mekis, E.: Canadian climate trends, 1950-2007, Canadian Biodiversity: Ecosystem Status and Trends 2010, Technical Thematic Report No. 5, Canadian Councils of Resource Ministers, Ottawa, ON, IV + 21 pp., http://www.biodivcanada.ca/default.asp?lang= En\&n=137E1147-0, 2011. 